\title{
EFFECTS OF LEAD ON GROWTH, YIELD AND MINERAL NUTRITION OF RICE (Oryza sativa L.)
}

\author{
Jasmin, P., W. Z. Prian ${ }^{1}$, M. N. Mondol ${ }^{1}$, S. M. Ullah ${ }^{1}$ and A. S. Chamon ${ }^{1}$ \\ Department of Soil Science, Mirpur Bangla College, Mirpur, Dhaka, Bangladesh; ${ }^{1}$ Department of Soil, \\ Water and Environment, University of Dhaka, Dhaka-1000, Bangladesh
}

\begin{abstract}
A pot experiment was conducted to evaluate the effect of lead (50, 100, 150 and $\left.200 \mathrm{mg} \mathrm{kg}^{-1}\right)$ on rice (Oryza sativa) and remediation of metal contamination by applying cow dung, poultry litter and lime to alleviate lead toxicity. The lengths, fresh and dry weights of shoot, root and macronutrients decreased with increasing level of lead compared to the control. The maximum reduction was observed in the pots treated with $200 \mathrm{mg} \mathrm{kg}^{-1}$ lead (19.50 and $20.03 \%$ for grain, 17.15 and $19.75 \%$ for shoot and 17.96 and $30.02 \%$ for root on the fresh and dry weight, respectively). The highest reduction in macronutrient content was observed in 200 $\mathrm{mg} \mathrm{kg}^{-1}$ lead treated pot where $\mathrm{N}, \mathrm{P}, \mathrm{K}, \mathrm{Ca}$ and $\mathrm{Mg}$ concentrations were reduced by $31.14,47.44,22.49,21.84$ and $31.58 \%$ for shoot and $28.95,55.64,37.5,49.33$ and $23 \%$ for root, respectively. On the other hand lead concentration in roots and shoots were increased with increasing lead treatment compared to the control. Treatments of the amendments (cow dung, poultry litter and lime) had positive effects though cow dung outshining the rest of them. This particular organic matter had considerable decreasing impacts in lead uptake by rice. Cow dung treated pots increased fresh and dry weight by 31.48 and $32.07 \%$ for grain, 14.08 and $35.30 \%$ for shoot and 57.09 and $34.48 \%$ for root compared to pot treated with $100 \mathrm{mg} \mathrm{kg}^{-1}$ lead. Cow dung remediated lead concentration by $48.85,65.00$ and $62.00 \%$ for grain, shoot and root, respectively.
\end{abstract}

Key words: Lead; Amendments; Cow dung; Poultry litter; Lime; Bridhan-49.

\section{INTRODUCTION}

Lead toxicity has increased in Bangladesh due to increased disposal of municipal and industrial solid and liquid wastes, vehicle exhausts to the soil (Kibria, 2013). With sharp rise in the use of motor vehicles, use of lead acid battery (LAB) has also increased in Bangladesh and as a result, manufacturing of LAB has also increased proportionally (Ahmad et al., 2014). Workers in these industries are at constant risk of exposure of lead and thus increasing lead content I soil (Ahmad et al., 2014). When lead present at an elevated level in soil, are absorbed by the root system, accumulate in different parts of plants, reduce their growth and impairs metabolism. Lead pollution coats the surface of the leaves and reduces the amount of light reaching it and as a result the growth of crops has become stunted or killing the plants by reducing photosynthesis, inhibiting respiration, encouraging an elongation of plant cells influencing root development by causing pre-mature aging (Chamon et al.,2005a).

Rice seed germination rate and the amount/qualityof chlorophyll decrease remarkably with increasing lead concentration. The decrease in grain yield of rice due to lead toxicity was reported by Chatterjee et al. (2004).

Lead works as a dangerous neurotoxin to human and animals. WHO (2009) documented that lead exposure accounts for about $0.6 \%$ of the global burden of diseases, particularly in developing nations. According to Bangladesh Bureau of Statistics (BBS 2004) throughout the country, 22,480 persons were engaged in the battery recharging/recycling establishments and about one-fourth $(24.6 \%)$ of them are child workers (5-17 years). There is adequate chance of exposure to lead among the workers as the health of them in these establishments is much neglected leading to the risk of lead contamination and development of severe health hazard.

Trace metal contaminated sites are of a great concern in this rapidly growing trend of urbanization and industrialization and requires remediation of polluted sites. Organic matter amendments are highly 
effective because of their inexpensive and ready availability and additional benefits for plant growth and soil properties and the addition of organic matter substantially reduce metal uptake was reported by Bassuk (1986).

Considering the above findings, two separate pot experiments were performed to investigate the effect of lead on growth, yield and nutrition of rice as well as to observe the effect of amendments like cow dung, poultry litter and lime for remediation of lead contamination.

\section{MATERIAL AND METHODS}

Pot experiments were conducted at the experimental field of Soil Science Department, Government Bangla College, Mirpur, Dhaka during June, 2011 to June, 2012. The soils used for pot experiments belongs to Belabo series under the Agro-ecological zone, Madhupur Tract (AEZ-28) comprising of moderately well drained, yellow-brown, mottled clays occupying level upland sites. Physical, chemical and physico-chemical properties of the experimental soil were determined (according to Jackson, 1962 and Black, 1965) (texture: silt loam, pH: 6.05, Ec: $105.4 \mathrm{~ms}, \%$ organic matter: 0.79 and total lead: 10 $\mathrm{mg} \mathrm{kg}^{-1}$. (Must quote individual reference for each parameter)

Pot experiments were conducted with uncontaminated above mentioned soil to study the effects of different doses of lead $(0,50,100,150$, and $200 \mathrm{mg} / \mathrm{kg}\}$ and the ameliorating effects of cow dung, poultry litter and lime on rice (Bridhan-49). Plastic pots were filled with $8 \mathrm{~kg}$ soil with three replications of each treatment and arranged in completely randomized design. Basal dose of fertilizers were added at medium rate for rice (3 plants/pot, another sentence) (BARC 2012) Rewrite mentioning the rates. The crops were harvested at maturity. Treatment of lead was applied as lead acetate (dissolved in water). The treatment combinations are given in Table 1. Second pot experiment was done to follow remediation of lead by using cow dung, poultry litter and lime at the rate of 20,20 and $5 \mathrm{t} / \mathrm{ha}$, respectively.

Table 1. Treatment combinations for two pot experiments.

\begin{tabular}{|c|c|c|c|}
\hline \multicolumn{2}{|c|}{ Different doses } & \multicolumn{2}{|c|}{ Amendments } \\
\hline \multicolumn{2}{|c|}{ Treatments } & Tre & nts \\
\hline $\mathrm{T}_{0}$ & 0 (Control) & $\mathrm{T}_{0}$ & 0 (Control) \\
\hline $\mathrm{T}_{1}$ & $50 \mathrm{mg} \mathrm{kg}^{-1} \mathrm{~Pb}$ & $\mathrm{~T}_{1}$ & $100 \mathrm{mg} \mathrm{kg}^{-1} \mathrm{~Pb}$ \\
\hline $\mathrm{T}_{2}$ & $100 \mathrm{mg} \mathrm{kg}^{-1} \mathrm{~Pb}$ & $\mathrm{~T}_{2}$ & $100 \mathrm{mg} \mathrm{kg}^{-1} \mathrm{~Pb}+$ Cow dung $(20 \mathrm{t} / \mathrm{ha})$ \\
\hline $\mathrm{T}_{3}$ & $150 \mathrm{mg} \mathrm{kg}^{-1} \mathrm{~Pb}$ & $\mathrm{~T}_{3}$ & $100 \mathrm{mg} \mathrm{kg}^{-1} \mathrm{~Pb}$ Poultry litter (20 t/ha) \\
\hline $\mathrm{T}_{4}$ & $200 \mathrm{mg} \mathrm{kg}^{-1} \mathrm{~Pb}$ & $\mathrm{~T}_{4}$ & $100 \mathrm{mg} \mathrm{kg}^{-1} \mathrm{~Pb}$ Lime $(5 \mathrm{t} / \mathrm{ha})$ \\
\hline
\end{tabular}

Soil samples were digested with $\mathrm{HCl}: \mathrm{HNO}_{3}(3: 1)$, and plant samples with a $\mathrm{HNO}_{3}: \mathrm{HClO}_{4}(5: 1)$ mixture in closed systems (Blum et al., 1996). All elements were measured in the extracts by Atomic Absorption Spectroscopy (AAS).

The collected data on plant parameters and mineral nutrition were statistically analyzed by using ANOVA (analysis of variance) and Duncan's Multiple Range Test (DMRT) in IBM SPSS statistics version 20 as outlined by Gomez and Gomez (1984). The letter was used for testing the significant of variation between mean values. The 0.05 level of probability was chosen for the statistical judgment. 


\section{RESULTS AND DISCUSSION}

\section{Effects of different doses of Lead $(\mathrm{Pb})$ on growth, yield and mineral nutrition of rice (variety: BRRI Dhan-49)}

\section{Growth and yield parameters}

The mean values of fresh and dry wt (g/pot) of rice grains were affected considerably by different lead treatments (Table 2). The highest fresh and dry weights of grains (33.01 and $23.92 \mathrm{~g} / \mathrm{pot}$ ) were obtained in the control treatment $\left(\mathrm{T}_{0}\right)$ where no lead was applied. The lowest values (26.57 and $19.13 \mathrm{~g} / \mathrm{pot}$ ) were obtained with the treatment $\mathrm{T}_{4}$ (at $200 \mathrm{mg} \mathrm{kg}^{-1} \mathrm{~Pb}$ ). Application of $200 \mathrm{mg} \mathrm{kg}^{-1}$ lead reduced fresh and dry weight of grain by 19.5 and $20 \%$, respectively, compared to the control treatment. The increasing concentration of lead produced lower grain yield of rice compared to the control (Table 2). It was evident from the observed data that lead application significantly reduced the fresh and dry weight of shoot and root with increasing lead treatment from 50 to $200 \mathrm{mg} \mathrm{kg}^{-1}$ of lead/pot.

Table 2a. Effect of different doses of lead on growth and yield parameters of rice.

\begin{tabular}{l|ccc|ccc|ccc}
\hline \multirow{2}{*}{ Treatments } & \multicolumn{3}{|c|}{ Fresh wt. (g/pot) } & \multicolumn{3}{c|}{ Dry wt. (g/pot) } & \multicolumn{3}{c}{ Length (cm/pot) } \\
\cline { 2 - 10 } & Grain & Shoot & Root & Grain & Shoot & Root & Panicle & Shoot & Root \\
\hline $\mathrm{T}_{0}($ Control) & $33.01 \mathrm{a}$ & $68.57 \mathrm{a}$ & $23.32 \mathrm{a}$ & $23.92 \mathrm{a}$ & $25.12 \mathrm{a}$ & $4.23 \mathrm{a}$ & $25.00 \mathrm{a}$ & $106.33 \mathrm{a}$ & $26.33 \mathrm{a}$ \\
$\mathrm{T}_{1}\left(50 \mathrm{mg} \mathrm{kg}^{-1} \mathrm{~Pb}\right)$ & $33.11 \mathrm{a}$ & $65.24 \mathrm{a}$ & $23.05 \mathrm{a}$ & $22.25 \mathrm{ab}$ & $23.17 \mathrm{ab}$ & $3.77 \mathrm{ab}$ & $23.67 \mathrm{ab}$ & $106.00 \mathrm{a}$ & $26.33 \mathrm{a}$ \\
$\mathrm{T}_{2}\left(100 \mathrm{mg} \mathrm{kg}^{-1} \mathrm{~Pb}\right)$ & $32.53 \mathrm{a}$ & $61.71 \mathrm{ab}$ & $20.18 \mathrm{~b}$ & $20.30 \mathrm{ab}$ & $21.22 \mathrm{bc}$ & $3.69 \mathrm{ab}$ & $23.33 \mathrm{ab}$ & $103.67 \mathrm{~b}$ & $22.33 \mathrm{ab}$ \\
$\mathrm{T}_{3}\left(150 \mathrm{mg} \mathrm{kg}^{-1} \mathrm{~Pb}\right)$ & $28.47 \mathrm{ab}$ & $57.84 \mathrm{~b}$ & $19.73 \mathrm{~b}$ & $19.13 \mathrm{~b}$ & $20.19 \mathrm{c}$ & $3.34 \mathrm{ab}$ & $23.00 \mathrm{~b}$ & $102.33 \mathrm{~b}$ & $21.67 \mathrm{~b}$ \\
$\mathrm{~T}_{4}\left(200 \mathrm{mg} \mathrm{kg}^{-1} \mathrm{~Pb}\right)$ & $26.57 \mathrm{~b}$ & $56.81 \mathrm{~b}$ & $17.44 \mathrm{c}$ & $19.13 \mathrm{~b}$ & $20.16 \mathrm{c}$ & $2.96 \mathrm{~b}$ & $22.67 \mathrm{~b}$ & $100.00 \mathrm{c}$ & $21.33 \mathrm{~b}$ \\
\hline
\end{tabular}

Table 2b.Effect of different doses of lead on growth and yield parameters of rice.

\begin{tabular}{lcccc}
\hline Treatments & No. of tiller/3 plant & No. of Panicle/3 plant & No. of grain/panicle & 1000 grain wt. (g/pot) \\
\hline $\mathrm{T}_{0}($ Control $)$ & $11.33 \mathrm{a}$ & $10.00 \mathrm{a}$ & $182.00 \mathrm{a}$ & $18.60 \mathrm{a}$ \\
$\mathrm{T}_{1}\left(50 \mathrm{mg} \mathrm{kg} \mathrm{g}^{-1} \mathrm{~Pb}\right)$ & $9.66 \mathrm{~b}$ & $9.67 \mathrm{a}$ & $178.00 \mathrm{a}$ & $17.63 \mathrm{ab}$ \\
$\mathrm{T}_{2}\left(100 \mathrm{~g} \mathrm{~kg}^{-1} \mathrm{~Pb}\right)$ & $9.33 \mathrm{~b}$ & $9.33 \mathrm{ab}$ & $167.00 \mathrm{~b}$ & $16.90 \mathrm{ab}$ \\
$\mathrm{T}_{3}\left(150 \mathrm{mg} \mathrm{kg}^{-1} \mathrm{~Pb}\right)$ & $9.33 \mathrm{~b}$ & $9.00 \mathrm{ab}$ & $159.33 \mathrm{bc}$ & $16.40 \mathrm{~b}$ \\
$\mathrm{~T}_{4}\left(200 \mathrm{mg} \mathrm{kg}^{-1} \mathrm{~Pb}\right)$ & $9.00 \mathrm{~b}$ & $8.33 \mathrm{~b}$ & $150.33 \mathrm{c}$ & $15.87 \mathrm{~b}$ \\
\hline
\end{tabular}

Means followed by the same letter (s) in a column do not differ significantly from each other at 5\% level by DMRT

At the highest dose of lead $\left(200 \mathrm{mgkg}^{-1}\right)$ treated pots, shoot and root length of rice decreased by 6.0 and $19.0 \%$, respectively, compared with the control. The number of tiller/pot and 1000 grains weight (g/pot) of rice differed significantly among different treatment levels. The highest tiller number and 1000 grains weight were found (11.33 and $18.60 \mathrm{~g} / \mathrm{pot}$, respectively) in the control treatment and the lowest were (9.00 and $15.87 \mathrm{~g} /$ pot respectively,) in the $\mathrm{T}_{4}$ treatment (at $200 \mathrm{mg} \mathrm{kg}^{-1}$ of $\mathrm{Pb}$ ).

Mahmood et al. (2007) stated that root length of rice seedlings at both 5 and $10 \mathrm{mM}$ lead was significantly less (30-50\%) than that of the control seedlings. Ullah et al. (2011) also showed that lead toxicity significantly affected fresh and dry weights of grain yield of rice grown in pots. Similarly Kibria et al. (2009) found shoot and root weights of A. gangeticus and A. oleracea declined by 28 and $46 \%$ (for shoot) and 53 and $37 \%$ (for root) over control at the highest rate $\left(100 \mathrm{mg} \mathrm{kg}^{-1}\right)$ of lead application. Furthermore, the inhibition of root growth may be due to a decrease in calcium in root tips, leading to a decrease in cell division or cell elongation (Eun et al.2000). Also Israret al. (2011) found lead induced oxidative stress in Sesbania drummondii. 


\section{Mineral Nutrients}

Application of different doses of lead decreased nitrogen concentration in root and shoot of rice (variety: Bridhan-49) but in case of grain nitrogen concentration increased significantly up to $100 \mathrm{mg}$ $\mathrm{kg}^{-1}$ of lead treated pots and then decreased with increasing level of lead (Table 3) because of antagonistic effect of lead with nitrogen. The maximum amount of $\mathrm{P}, \mathrm{K}$ and $\mathrm{Mg}$ were found in the control $\left(\mathrm{T}_{0}\right)$ treatment and the lowest in the $200 \mathrm{mg} \mathrm{kg}^{-1}$ of lead treated pots $\left(\mathrm{T}_{4}\right)$ in case of root, shoot and grain (Table 3) because of antagonistic effect of $\mathrm{Pb}$ with macronutrients reported by many authors (Sharma and Dubey 2005, Chamon et al.2005a). Calcium concentration in root and grain of rice was significantly decreased by lead application whereas in case of shoot, calcium concentration was less affected.

Table 3a.Effects of different doses of lead on mineral nutrition of Rice.

\begin{tabular}{l|ccc|ccc|ccc}
\hline \multirow{2}{*}{ Treatment } & \multicolumn{3}{|c|}{ Nitrogen\% } & \multicolumn{3}{c|}{ Phosphorus\% } & \multicolumn{3}{c}{ Potassium\% } \\
\cline { 2 - 9 } & Root & Shoot & Grain & Root & Shoot & Grain & Root & Shoot & Grain \\
\hline $\mathrm{T}_{0}($ Control $)$ & $0.418 \mathrm{a}$ & $0.353 \mathrm{a}$ & $0.505 \mathrm{~d}$ & $0.408 \mathrm{a}$ & $0.078 \mathrm{a}$ & $0.239 \mathrm{a}$ & $0.656 \mathrm{a}$ & $2.09 \mathrm{a}$ & $0.203 \mathrm{a}$ \\
$\mathrm{T}_{1}\left(50 \mathrm{mg} \mathrm{kg}^{-1} \mathrm{~Pb}\right)$ & $0.386 \mathrm{a}$ & $0.317 \mathrm{~b}$ & $0.591 \mathrm{~b}$ & $0.302 \mathrm{~b}$ & $0.069 \mathrm{ab}$ & $0.225 \mathrm{ab}$ & $0.630 \mathrm{a}$ & $1.83 \mathrm{ab}$ & $0.191 \mathrm{ab}$ \\
$\mathrm{T}_{2}\left(100 \mathrm{~m} \mathrm{~kg}^{-1} \mathrm{~Pb}\right)$ & $0.374 \mathrm{a}$ & $0.302 \mathrm{~b}$ & $0.649 \mathrm{a}$ & $0.241 \mathrm{bc}$ & $0.062 \mathrm{ab}$ & $0.219 \mathrm{abc}$ & $0.547 \mathrm{ab}$ & $1.80 \mathrm{ab}$ & $0.187 \mathrm{ab}$ \\
$\mathrm{T}_{3}\left(150 \mathrm{mg} \mathrm{kg}^{-1} \mathrm{~Pb}\right)$ & $0.367 \mathrm{a}$ & $0.253 \mathrm{c}$ & $0.584 \mathrm{~b}$ & $0.223 \mathrm{c}$ & $0.049 \mathrm{ab}$ & $0.203 \mathrm{bc}$ & $0.540 \mathrm{ab}$ & $1.64 \mathrm{~b}$ & $0.183 \mathrm{ab}$ \\
$\mathrm{T}_{4}\left(200 \mathrm{mg} \mathrm{kg}^{-1} \mathrm{~Pb}\right)$ & $0.297 \mathrm{~b}$ & $0.241 \mathrm{c}$ & $0.558 \mathrm{c}$ & $0.181 \mathrm{c}$ & $0.041 \mathrm{~b}$ & $0.198 \mathrm{c}$ & $0.410 \mathrm{~b}$ & $1.62 \mathrm{~b}$ & $0.171 \mathrm{~b}$ \\
\hline
\end{tabular}

Table 3b.Effects of different doses of lead on mineral nutrition of Rice.

\begin{tabular}{l|ccc|ccc|cc}
\hline \multirow{2}{*}{ Treatment } & \multicolumn{3}{|c|}{ Calcium\% } & \multicolumn{3}{c|}{ Magnesium\% } & \multicolumn{2}{c}{ Lead ( mg/kg) } \\
\cline { 2 - 8 } & Root & Shoot & Grain & Root & Shoot & Grain & Root & Shoot \\
\hline $\mathrm{T}_{0}($ Control $)$ & $0.446 \mathrm{a}$ & $0.403 \mathrm{a}$ & $0.028 \mathrm{a}$ & $0.213 \mathrm{a}$ & $0.152 \mathrm{a}$ & $0.096 \mathrm{a}$ & $42.5 \mathrm{~d}$ & $7.5 \mathrm{~d}$ \\
$\mathrm{~T}_{1}\left(50 \mathrm{mg} \mathrm{kg}^{-1} \mathrm{~Pb}\right)$ & $0.392 \mathrm{ab}$ & $0.393 \mathrm{ab}$ & $0.028 \mathrm{a}$ & $0.192 \mathrm{ab}$ & $0.117 \mathrm{~b}$ & $0.090 \mathrm{ab}$ & $206 \mathrm{c}$ & $7.5 \mathrm{~d}$ \\
$\mathrm{~T}_{2}\left(100 \mathrm{mg} \mathrm{kg}^{-1} \mathrm{~Pb}\right)$ & $0.323 \mathrm{bc}$ & $0.360 \mathrm{ab}$ & $0.025 \mathrm{a}$ & $0.178 \mathrm{ab}$ & $0.107 \mathrm{~b}$ & $0.084 \mathrm{bc}$ & $341 \mathrm{c}$ & $20.00 \mathrm{c}$ \\
$\mathrm{T}_{3}\left(150 \mathrm{mg} \mathrm{kg}^{-1} \mathrm{~Pb}\right)$ & $0.278 \mathrm{~cd}$ & $0.319 \mathrm{~b}$ & $0.022 \mathrm{ab}$ & $0.174 \mathrm{ab}$ & $0.105 \mathrm{~b}$ & $0.086 \mathrm{~cd}$ & $613 \mathrm{~b}$ & $30.00 \mathrm{~b}$ \\
$\mathrm{~T}_{4}\left(200 \mathrm{mg} \mathrm{kg}^{-1} \mathrm{~Pb}\right)$ & $0.226 \mathrm{~d}$ & $0.315 \mathrm{~b}$ & $0.018 \mathrm{~b}$ & $0.164 \mathrm{~b}$ & $0.104 \mathrm{~b}$ & $0.075 \mathrm{~d}$ & $1577 \mathrm{a}$ & $43.17 \mathrm{a}$ \\
\hline
\end{tabular}

Means followed by the same letter (s) in a column do not differ significantly from each other at 5\% level by DMRT

Kibria et al. (2009) reported that lead application in soil significantly increased $\mathrm{Pb}$ concentration in shoot of $A$. oleracea. On the contrary Ullah et al. (2011) reported an antagonistic effect on nitrogen uptake by rice due to application of lead. These variation in $\mathrm{N}$ concentration in root, shoot and grain of rice, probably due to difference in plant variety. In most cases, lead blocks the entry of $\mathrm{N}, \mathrm{P}, \mathrm{K}, \mathrm{Ca}$ and $\mathrm{Mg}$ in the root system (Sharma and Dubey 2005,Chamon et al.2005a).

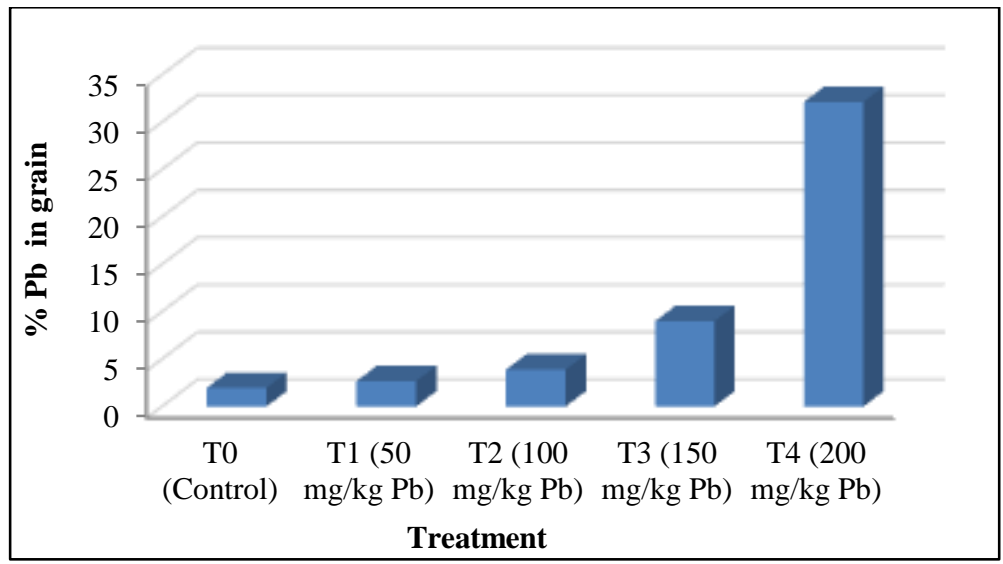

Fig. 1.Effects of different levels of lead in rice grain 


\section{Lead concentration}

Lead application in soil significantly increased the lead concentration in root, shoot and grain of rice (variety: Bridhan-49) (Fig. 1). Lead concentration in root, shoot and grain appears to be very high. At $200 \mathrm{mg} \mathrm{kg}^{-1}$ of lead treatment the $\mathrm{Pb}$ concentration were found to be 1577, 43.17 (Table 3) and 32.13 $\mathrm{mg} / \mathrm{kg}$ (Fig. 1) in root, shoot and grain, respectively. Different parts of the plant absorb different quantities of heavy metals; the higher values were found in roots and leaves and the least amounts were found in fruits and seeds as reported by Natasa et al. (2015). Accumulation and distribution of lead in the plants depend on the plant species, the element species and bioavailability, $\mathrm{pH}$, cation exchange capacity, atmospheric condition, vegetation period and multiple other factors (Chamon et al. 2005a).

\section{Growth, yield and mineral nutrition of Rice (variety: Bridhan-49), influenced by different amendments}

\section{Growth and yield parameters}

Fresh and dry weights of grain (g/pot) of rice (variety: Bridhan-49) was considerably affected by the application of different amendments which were artificially contaminated with $100 \mathrm{mg} \mathrm{kg}^{-1}$ of lead (Table 4a).

Table 4a. Effects of different amendments on growth and yield parameters of rice (variety: Bridhan-49).

\begin{tabular}{|c|c|c|c|c|c|c|c|c|c|}
\hline \multirow[t]{2}{*}{ Treatment } & \multicolumn{3}{|c|}{ Fresh wt. (g/pot) } & \multicolumn{3}{|c|}{ Dry wt. (g/pot) } & \multicolumn{3}{|c|}{ Length $(\mathrm{cm} /$ pot) } \\
\hline & Grain & Shoot & Root & Grain & Shoot & Root & Panicle & Shoot & Root \\
\hline T0 (Control) & $33.01 \mathrm{~b}$ & $66.57 \mathrm{ab}$ & $23.32 \mathrm{~b}$ & $23.92 \mathrm{~b}$ & $25.12 \mathrm{~b}$ & $4.23 \mathrm{a}$ & $25.00 \mathrm{a}$ & $106.33 \mathrm{ab}$ & $26.33 \mathrm{a}$ \\
\hline $\mathrm{T} 1\left(100 \mathrm{mg} \mathrm{kg}^{-1} \mathrm{~Pb}\right)$ & $32.53 \mathrm{~b}$ & $61.70 \mathrm{~b}$ & $20.18 b$ & $20.30 \mathrm{~b}$ & $21.22 \mathrm{c}$ & $3.77 \mathrm{a}$ & $23.33 \mathrm{~b}$ & $103.67 \mathrm{~b}$ & $21.67 \mathrm{ab}$ \\
\hline $\begin{array}{l}\mathrm{T} 2 \quad(100 \mathrm{mg} \\
\text { cowdung (20 t/ha) }\end{array}$ & $42.77 \mathrm{a}$ & $70.39 \mathrm{a}$ & $31.70 \mathrm{a}$ & $26.81 \mathrm{a}$ & $28.71 \mathrm{a}$ & $5.07 \mathrm{a}$ & $25.33 \mathrm{a}$ & $108.00 \mathrm{a}$ & $25.00 \mathrm{ab}$ \\
\hline $\begin{array}{l}\text { T3 } \quad\left(100 \quad \mathrm{mg} \quad \mathrm{kg}^{-1} \mathrm{~Pb}+\right. \\
\text { poultry litter }(20 \mathrm{t} / \mathrm{h})\end{array}$ & $36.18 \mathrm{~b}$ & $63.84 \mathrm{ab}$ & $20.43 \mathrm{~b}$ & $23.38 \mathrm{~b}$ & $24.07 \mathrm{bc}$ & $3.86 \mathrm{a}$ & $24.33 \mathrm{ab}$ & $105.67 \mathrm{ab}$ & $21.00 \mathrm{ab}$ \\
\hline $\begin{array}{l}\text { T4 (100 mg kg }{ }^{-1} \mathrm{~Pb}+\text { lime } \\
(5 \mathrm{t} / \mathrm{ha})\end{array}$ & $37.61 \mathrm{ab}$ & $59.80 \mathrm{~b}$ & $19.82 \mathrm{~b}$ & $23.02 \mathrm{~b}$ & $21.14 \mathrm{c}$ & $3.48 \mathrm{a}$ & $25.00 \mathrm{a}$ & $104.64 \mathrm{ab}$ & $19.67 \mathrm{~b}$ \\
\hline
\end{tabular}

Application of $100 \mathrm{mg} \mathrm{kg}^{-1}$ of lead decreased 1.5 and $15.1 \%$ fresh and dry weight of grains compared to the control. Among amendments cow dung increased by 31.5 and $32.1 \%$ fresh and dry weight of grain compared with $100 \mathrm{mg} \mathrm{kg}^{-1}$ lead treatments. This might be due to the ameliorating effect of cow dung against lead toxicity hence increase yield of rice grain.

However, in case of fresh weight of shoot, treatment did not differ significantly. The highest fresh and dry weight was observed in cow dung (31.70 and $5.07 \mathrm{~g} / \mathrm{pot})$ and the lowest in lime (19.82 and 3.48 $\mathrm{g} / \mathrm{pot}$ ) treatment. Cow dung and poultry litter treatments increased fresh and dry weights of root whereas lime decreased the root biomass production (Table 4a).

Application of lead significantly declined the number of tiller/pot, panicle/pot and 1000 grain weight (g/pot) compared with the control treatment (Table 4b). The highest number of tiller/pot and panicle/pot were observed in pots treated with cow dung followed by lime and poultry litter. Cow dung treated pots also showed the highest 1000 grains weight followed by poultry litter and lime.

Overall it was evident that cow dung has a splendid role in reducing lead toxicity in rice growth parameters. Similar results were reported previously by many authors (Chamon et al. 2005b, Mondol et al.2019, Mahajabin et al. 2019). Nuruzzaman et al. (1995) observed that the dry matter yield of rice grain was increased by $27 \%$ by $40 \mathrm{Mt}$ cow dung/ha. Application of poultry litter and used tea leaves as organic amendments enhanced the growth of red amaranth (Mondol et al. 2019). 
Table 4b. Effects of different amendments on growth and yield parameters of rice (variety: Bridhan-49).

\begin{tabular}{|c|c|c|c|c|}
\hline Treatment & No. of tiller/3 plant & No. of Panicle/3 plant & $\begin{array}{c}\text { No. of } \\
\text { grain/panicle }\end{array}$ & 1000 grain wt. (g/pot) \\
\hline T0 (Control) & $11.33 \mathrm{~b}$ & $10.00 \mathrm{c}$ & $178.00 \mathrm{ab}$ & $18.60 \mathrm{a}$ \\
\hline $\mathrm{T} 1\left(100 \mathrm{mg} \mathrm{kg}^{-1} \mathrm{~Pb}\right)$ & $9.33 \mathrm{c}$ & $9.33 \mathrm{c}$ & $167.00 \mathrm{~b}$ & $16.93 \mathrm{~b}$ \\
\hline $\begin{array}{l}\text { T2 }\left(100 \mathrm{mg} \mathrm{kg}^{-1} \mathrm{~Pb}+\right. \\
\text { cowdung (20 t/ha) }\end{array}$ & $14.67 \mathrm{a}$ & $14.67 \mathrm{a}$ & $196.67 \mathrm{a}$ & $19.28 \mathrm{a}$ \\
\hline $\begin{array}{l}\mathrm{T} 3\left(100 \mathrm{mg} \mathrm{kg}{ }^{-1} \mathrm{~Pb}+\right. \\
\text { poultry litter }(20 \mathrm{t} / \mathrm{ha})\end{array}$ & $10.00 \mathrm{c}$ & $9.67 \mathrm{c}$ & $196.00 \mathrm{a}$ & $18.39 \mathrm{a}$ \\
\hline $\begin{array}{l}\text { T4 }\left(100 \mathrm{mg} \mathrm{kg}{ }^{-1} \mathrm{~Pb}+\right. \\
\text { lime }(5 \mathrm{t} / \mathrm{ha})\end{array}$ & $12.33 \mathrm{~b}$ & $11.67 \mathrm{~b}$ & $189.33 \mathrm{ab}$ & $18.16 \mathrm{a}$ \\
\hline
\end{tabular}

Means followed by the same letter(s) in a column do not differ significantly from each other at 5\% level by DMRT

\section{Mineral nutrients}

Application of lead reduced nutrient concentration in root, shoot and grain of rice when compared with the control but with addition of amendments macronutrient concentration increased in comparison with the unamended pots (Table 5a). Nitrogen concentrations in root and shoot were decreased by 10.52 and $14.44 \%$, respectively and increased by $28.76 \%$ in grain with application of $100 \mathrm{mg} \mathrm{kg}^{-1}$ of lead treatment compared with the control. The highest concentration was observed with cow dung followed by poultry litter and lime in root and shoot but in grain, the highest concentration being observed with cow dung followed by lime and poultry litter, respectively.

Table 5a. Effects of different amendments on mineral nutrition of Rice (variety: Bridhan- 49).

\begin{tabular}{|c|c|c|c|c|c|c|c|c|c|}
\hline \multirow[t]{2}{*}{ Treatment } & \multicolumn{3}{|c|}{ Nitrogen $\%$} & \multicolumn{3}{|c|}{ Phosphorus\% } & \multicolumn{3}{|c|}{ Potassium\% } \\
\hline & Root & Shoot & Grain & Root & Shoot & Grain & Root & Shoot & Grain \\
\hline T0 (Control) & $0.418 \mathrm{c}$ & $0.353 \mathrm{~b}$ & $0.504 \mathrm{e}$ & $0.408 \mathrm{c}$ & $0.078 \mathrm{~b}$ & $0.239 \mathrm{c}$ & $0.656 \mathrm{a}$ & $2.09 \mathrm{a}$ & $0.203 \mathrm{~b}$ \\
\hline $\mathrm{T} 1\left(100 \mathrm{mg} \mathrm{kg}^{-1} \mathrm{~Pb}\right)$ & $0.374 \mathrm{~d}$ & $0.302 \mathrm{c}$ & $0.649 \mathrm{~d}$ & $0.241 \mathrm{~d}$ & $0.062 \mathrm{~b}$ & $0.219 \mathrm{c}$ & $0.540 \mathrm{ab}$ & $1.80 \mathrm{a}$ & $0.187 \mathrm{~b}$ \\
\hline $\begin{array}{l}\text { T2 (100 mg kg-1 } \mathrm{Pb}+ \\
\text { cowdung }(20 \mathrm{t} / \mathrm{ha})\end{array}$ & $0.514 \mathrm{a}$ & $0.408 \mathrm{a}$ & $0.854 \mathrm{a}$ & $0.497 \mathrm{a}$ & $0.133 \mathrm{a}$ & $0.432 \mathrm{a}$ & $0.623 \mathrm{ab}$ & $1.91 \mathrm{a}$ & $0.427 \mathrm{a}$ \\
\hline $\begin{array}{l}\mathrm{T} 3\left(100 \mathrm{mg} \mathrm{kg}{ }^{-1} \mathrm{~Pb}+\right. \\
\text { poultry litter }(20 \mathrm{t} / \mathrm{ha})\end{array}$ & $0.490 \mathrm{ab}$ & $0.396 \mathrm{ab}$ & $0.713 \mathrm{c}$ & $0.456 \mathrm{~b}$ & $0.098 \mathrm{ab}$ & $0.393 \mathrm{a}$ & $0.496 \mathrm{~b}$ & $2.01 \mathrm{a}$ & $0.530 \mathrm{a}$ \\
\hline $\begin{array}{l}\text { T4 }\left(100 \mathrm{mg} \mathrm{kg}{ }^{-1} \mathrm{~Pb}+\right. \\
\text { lime }(5 \mathrm{t} / \mathrm{ha})\end{array}$ & $0.461 \mathrm{~b}$ & $0.371 \mathrm{ab}$ & $0.738 \mathrm{~b}$ & $0.384 \mathrm{~b}$ & $0.077 \mathrm{~b}$ & $0.310 \mathrm{~b}$ & $0.537 \mathrm{ab}$ & $2.09 \mathrm{a}$ & $0.483 \mathrm{a}$ \\
\hline
\end{tabular}

Table 5b. Effects of different amendments on mineral nutrition of Rice (variety: Bridhan- 49).

\begin{tabular}{|c|c|c|c|c|c|c|c|c|c|}
\hline \multirow[t]{2}{*}{ Treatment } & \multicolumn{3}{|c|}{ Calcium\% } & \multicolumn{3}{|c|}{ Magnesium \% } & \multicolumn{3}{|c|}{ Lead (mg/kg) } \\
\hline & Root & Shoot & Grain & Root & Shoot & Grain & Root & Shoot & Grain \\
\hline T0 (Control) & $0.446 \mathrm{c}$ & $0.403 \mathrm{a}$ & $0.028 \mathrm{a}$ & $0.213 \mathrm{~b}$ & $0.152 \mathrm{~b}$ & $0.096 \mathrm{a}$ & $42.5 \mathrm{~d}$ & $7.5 \mathrm{~b}$ & $1.96 \mathrm{c}$ \\
\hline $\mathrm{T} 1\left(100 \mathrm{mg} \mathrm{kg}^{-1} \mathrm{~Pb}\right)$ & $0.323 \mathrm{~d}$ & $0.360 \mathrm{a}$ & $0.025 \mathrm{ab}$ & $0.178 \mathrm{~b}$ & $0.107 \mathrm{c}$ & $0.084 \mathrm{c}$ & $341 \mathrm{a}$ & $20.00 \mathrm{a}$ & $3.93 \mathrm{a}$ \\
\hline $\begin{array}{l}\mathrm{T} 2 \text { (100 } \mathrm{mg} \mathrm{kg} \mathrm{kg}^{-1} \mathrm{~Pb}+ \\
\text { cowdung }(20 \mathrm{t} / \mathrm{ha})\end{array}$ & $0.691 \mathrm{ab}$ & $0.371 \mathrm{a}$ & $0.024 \mathrm{ab}$ & $0.333 \mathrm{a}$ & $0.195 \mathrm{a}$ & $0.098 \mathrm{a}$ & $210 c$ & $7.00 \mathrm{~b}$ & $2.01 \mathrm{c}$ \\
\hline $\begin{array}{l}\mathrm{T} 3\left(100 \mathrm{mg} \mathrm{kg}{ }^{-1} \mathrm{~Pb}+\right. \\
\text { poultry litter }(20 \mathrm{t} / \mathrm{ha})\end{array}$ & $0.661 \mathrm{~b}$ & $0.348 \mathrm{a}$ & $0.018 \mathrm{~b}$ & $0.213 \mathrm{~b}$ & $0.156 \mathrm{~b}$ & $0.093 \mathrm{ab}$ & $291 \mathrm{~b}$ & $7.5 \mathrm{~b}$ & $3.81 \mathrm{a}$ \\
\hline $\begin{array}{l}\text { T4 (100 mg kg-1 } \mathrm{Pb}+ \\
\text { lime }(5 \mathrm{t} / \mathrm{ha})\end{array}$ & $0.701 \mathrm{a}$ & $0.379 \mathrm{a}$ & $0.024 \mathrm{ab}$ & $0.201 \mathrm{~b}$ & $0.161 \mathrm{~b}$ & $0.075 \mathrm{c}$ & $229 c$ & $7.5 \mathrm{~b}$ & $3.02 \mathrm{~b}$ \\
\hline
\end{tabular}

Means followed by the same letter(s) in a column do not differ significantly from each other at 5\% level by DMRT

Cow dung treatment increased nitrogen concentrations by $22.96,15.58$ and $69.44 \%$ in root, shoot and grain, respectively, compared with the control and 37.43, 35.09 and 31.58\%, respectively, compared with $100 \mathrm{mg} \mathrm{kg}^{-1}$ lead treatment. The concentration of phosphorus in root, shoot and grain of rice were decreased significantly with addition of $100 \mathrm{mg} \mathrm{kg}^{-1}$ of lead treatment. The highest was observed in cow 
dung treated pots $(0.497,0.133$ and $0.432 \%)$ in root, shoot and grain, respectively. Cow dung, poultry litter and lime treatment increased phosphorus concentration.

Potassium concentration in grain was significantly influenced by the application of amendments. Application of $100 \mathrm{mg} \mathrm{kg}^{-1}$ of lead decreased potassium concentration in root, shoot and grain. In root, the highest potassium concentration was observed with cow dung treatment followed by lime and poultry litter. In shoot, the highest potassium concentration was observed with lime application followed by poultry litter and cow dung. Application of $100 \mathrm{mg} \mathrm{kg}^{-1}$ of lead reduced the calcium concentration of rice root, shoot and grain. Among amendments the highest was observed with lime treatment which was $57.17 \%$ and $117.02 \%$ higher than control and $100 \mathrm{mg} \mathrm{kg}^{-1}$ lead treatments in root, respectively. Application of lead decreased 16.43, 29.60 and 12.5\% magnesium concentration of rice root, shoot and grain, respectively, compared with the control treatment. The highest concentration of magnesium was observed with cow dung treatment in root, shoot and grain and was significantly differed from other treatments. In root, application of cow dung increased $56.33 \%$ and lime decreased $5.63 \%$ magnesium concentration compared with the control and 87.07, 19.66 and 12.92\% increased, with cow dung, poultry litter and lime treatments, respectively, compared with $100 \mathrm{mg} \mathrm{kg}^{-1}$ lead treatments (Table 5a and $5 b)$.

\section{Lead concentration}

Lead concentration in rice (variety: Bridhan-49) root, shoot and grain as affected by different amendments are presented in Table 5. Application of lead (100 mg kg-1) increased 16.43, 29.60 and $12.5 \%$ lead concentration in rice root, shoot and grain, respectively, compared with the control treatment. Lead concentration in root ranged between 42.5 to $341 \mathrm{mg} \mathrm{kg}^{-1}$ which was above the maximum permissible limits in plants according to Sauerbeck (1982) (MPL for plants in general 10-20 $\mathrm{mg} \mathrm{kg}^{-1}$ ). Soil amended with cow dung, poultry litter and lime reduced lead concentration in rice root, shoot and grain, probably due to binding up of lead rendering it less available to plants by organic manures. There might be an antagonistic effect of calcium on lead uptake by rice plants due to lime addition. Cow dung, poultry litter and lime decreased lead concentration by 38.41, 14.66 and $32.84 \%$ in root and 65.0, 62.5 and 62.5\% in shoot and 48.85, 3.05 and 23.15\% lead concentration in grain compared with $100 \mathrm{mg} \mathrm{kg}^{-1}$ lead treatment (Table 5).

All amendments decreased lead concentration in rice. Amongst amendments cow dung had the greatest ability to reduce lead toxicity in root, shoot and grain and followed by lime and poultry litter. The similar effects were found while reducing lead toxicity of wheat using farm yard manure (FYM) and poultry manure by Rehman et al. (2017). Chamonet al. (2005b) reported that all organic materials can be classified as less contaminated and suitable for agricultural use according to their heavy metal concentrations. The better role of organic amendment in reducing lead uptake than lime was also reported by Mahajabinet al. (2019).

Cow dung as an amendment worked against lead toxicity which is evident form the above findings. It is well known that organic matter is not only an aggregating agent, but also an improver of soil structure and the stability (Vaughan and Malcolm, 1985). Also soil organic matter adsorbs available lead ions, producing and preserving forms of lead that are less available for plant uptake or leaching (Zehetner and Wenzel 2000).

Different parts of the plant absorb different quantities of heavy metals; the highest were shown in roots and leaves and the least amount were found in fruits and seeds reported by Natasa et al. (2015). The different accumulation rate among different parts of the rice plant was most probably caused by the restricted translocation of toxic metals between roots and shoots (Brekken and Steinnes 2004). The restriction in the translocation of lead from roots to shoots and other above ground parts can be 
explained by a metal exclusion mechanism in roots by which plants avoid damages in their photosynthetic processes (Borisev et al. 2008). It was assumed that mycorrizhal associations can greatly reduce metal translocation from roots to shoots by binding metals on cell wall components or intracellular immobilization (De Maria et al. 2011).

Lead contamination above toxic level in plants reduces its productivity hence its overall growth and yield. Its remediation must be undertaken for protecting our natural environment as well as to ensure a stable and toxic free food source. Therefore it is a must to conduct suitable and appropriate research programs for remedying lead induced toxicity by using various amendments (both organic and inorganic) as well as encourage public awareness to reduce the contamination.

From this study it can be concluded that the amendments used were suitable for controlling lead contamination and increasing yield. Lead contamination in the grain, shoot and root was ameliorated significantly by applying the amendments especially cow dung which is available and affordable and has positive influence in improving the physical and chemical properties of soil as well as the other two additives. Overall the inflow of metals in agricultural fields needs to avoid, otherwise it will contribute to accumulate metals in human tissues through food chain transfer. Most importantly social awareness must be encouraged to reduce lead toxicity as most of this pollution occurs through anthropogenic causes.

\section{ACKNOWLEDGEMENTS}

The authors gratefully acknowledge the Department of Soil Science, Mirpur Bangla College, Dhaka, for providing land facilities in the college premises. The Department of Soil, Water and Environment, University of Dhaka has provided all analytical facilities to carry out the Ph.D. research work. The authors are grateful to the Department. The authors gratefully acknowledge financial supports granted by the University Grant Commission of Bangladesh.

\section{REFERENCES}

Ahmad, Sk. A., M. H. Khan, S. Khandker, A. F. M. Sarwar, N. Yasmin, M. H. Faruquee and R. Yasmin. 2014. Blood Lead Levels and Health Problems of Lead Acid Battery Workers in Bangladesh. Sci. World J. 2014: 1-7.

BBS (Bangladesh Bureau of Statistics). 2004. Baseline Survey on Child Workers in Battery Recharging/Recycling Sector 2003-2004, Planning Division, GoB.

BARC (Bangladesh Agricultural Research Council). 2012 Fertilizer Recommendation Guide-2012. Bassuk, N. L. 1986. Reducing lead uptake in lettuce. Horticul. Sci. 21(4): 993-995.

Black, C. A. 1965. Methods of Soil Analysis: part 1 and part 2. Society of Agronomy, Wisconsin, USA. $770 \mathrm{pp}$.

Blum, W. E. H., H. Spiegel, and W. W. Wenzel. 1996. Bodenzutstandsinventur.Konception, Durchführung und Bewertung, EmpfehlungenZurVereinheitlichung der Vorgangsweise in Österreich. 2nd ed. Bundesministeriumfür Land und Forstwirtschaft, Wien., pp. 102-103.

Borisev, M., S. Pajevic, N. Nikolic, A. Pilipovic, B. Krstic and S. Orlovic. 2008. Phytoextraction of $\mathrm{Cd}, \mathrm{Ni}$ and $\mathrm{Pb}$ Using Four Willow Clones (Salix spp.). Polish J. Environ. Stud. 18: 553-561.

Brekken, A. and E. Steinnes. 2004. Seasonal concentrations of cadmium and zinc in native pasture plants: consequences for grazing animals. Sci. Total Environ. 326: 181-195. 
Chamon, A. S., M. H. Gerzabek, M. N. Mondol, S. M. Ullah, M. Rahman and W. H. Blum. $2005 a$. Influence of soil amendments on heavy metal accumulation in crops on polluted soils of Bangladesh. Comm. Soil Sci. Plant Anal. 36: 907-924.

Chamon, A. S., Gerzabek, M. H., Mondol, M. N., Ullah, S. M., Rahman, M. and Blum, W. H. 2005 b. Heavy metal uptake into crops on polluted soils of Bangladesh. I. Influence of crop and crop varieties. J. Comm. Soil Sci. Plant Anal. 36: 39.

Chatterjee, C., B. K. Dube, P. Sinha and P. Srivastava. 2004. Detrimental Effects of Lead Phytotoxicity on Growth, Yield, and Metabolism of Rice. J. Comm. Soil Sci. Plant Anal. 35: 255-265.

De Maria, S., A. R. Rivelli, M. Kuffner, A. Sessitsch, W. W. Wenzel, M. Gorfer, J. Strauss and M. Puschenreiter. 2011. Interactions between accumulation of trace elements and macronutrients in Salix caprea after inoculation with rhizosphere microorganisms. Chemosphere. 84(9): 1256-1261.

Eun, S. O., H. S. Youn and Y. Lee. 2000. Lead disturbs microtubule organization in the root meristem of Zea mays. Physiologia Plantarum. 110(3): 357-365.

Gomez, A. K. and A. A. Gomez. 1984. Statistical procedures for Agricultural Research. 2nd ed. John Wiley and Sons, New york, USA. 704 pp.

Israr, M., A. Jewell, D. Kumar and S. V. Sahi. 2011. Interactive effects of lead, copper, nickel and zinc on growth, metal uptake and antioxidative metabolism of Sesbania drummondii. J. Hazard Mater. 186: $1520-1526$.

Jackson, M. L. 1962. Soil Chemical Analysis. Prentice hall, Englewood cliffs, NJ, USA., pp. 1-48.

Kibria, M. G., M. Islam and K. T. Osman. 2009. Effects of lead on growth and mineral nutrition of Amaranthus gangeticus L. and Amaranthus oleracea L. Soil and Environ. 28(1):1-6.

Kibria, M. G. 2013. Dynamics of Cadmium and Lead in Some Soils of Chittagong, Bangladesh. IOSR J. Environ. Sci. Toxicol. Food Technol. 2: 64-71.

Mahajabin, S., S. Rahman, A. S. Chamon, M. N. Mondol and M. Rahman. 2019. Effect of Eggshell and Lime on Growth and Mineral nutrition of Kalmi (Ipmoea aquatica convolvulaceae) Grown on Lead Contaminated Soil. J. biodivers. conserv. bioresour. manag. 5(1): 85-92.

Mahmood, T. K., R. Islam and S. Muhammad. 2007. Toxic effects of heavy metals on early growth and tolerance of cereal crops. Pak. J. Bot. 39(2): 451-462.

Mondol, M. N., K. A. Hussain, A. S. Chamon, M. R. Zubaer and M. A. Hossain. 2019. Amelioration of lead $(\mathrm{Pb})$ from contaminated soil using organic amendments. Bangladesh J. Sci. Ind. Res. 54(2): 177-186.

Natasa, M., A. Rukie, S. Ljubomir, M. Lidijia and S. I. Zoran. 2015. Transfer factor as indicator of heavy metals content in plants. Fresentius Environ. Bull. 24(11c): 4212-4218.

Nuruzzaman, M., M. H. Gerzabek and S. M. Ullah. 1995. Studies on Heavy Metal and Microbiological Pollution of Soils, Sediments and Water Systems in and Around Dhaka City; Bericht an die O"sterr. Akademieder Wissenschaften, Austrain Research Centers, Seibersdorf. Austria., pp. 1-15.

Rehman, M. Z., M. Rizwan, S. Ali, M. Sabir and M. I. Sohail. 2017. Contrasting Effects of Organic and Inorganic Amendments on Reducing Lead Toxicity in Wheat. Bull. Environ. Contam. Toxicol. 99: 642-647. 
Sauerbeck, D. 1982. Welch Schwermetallgehalte in Pflanzen du"rfen nichtu"berschrit ten werden, um Wachstumsbeeintra"chtigungen $\mathrm{zu}$ vermeiden? Landwintschaftlicke Forschung Sonderheft, Kongressband. 39: 108-129.

Sharma, P. and R. S. Dubey. 2005. Lead toxicity in plants. Brazillian J. Plant Physiol. 17: 35-52.

Ullah, S. M., A. T. M. M. Kamal, S. G. Al-Neyam, A. M. M. Faizullah and S. Jahan. 2011. Effect of Lead on growth and mineral content of rice. (Oryza sativa L.). Bangladesh J. Sci. Res. 24(1): 67-74.

Vaughan, D. and R. E. Malcolm. 1985. Soil organic matter and biological activity. Martinus Nijhoff/Dr. W. Junk Publishers, Dordrecht, Boston, Lancaster. 486 pp.

WHO (World Health Organization). 2009. Global health Risks: Mortality and burden of disease attributable to selected major risks. Geneva, Switzerland.

Zehetner, F. and W. W. Wenzel. 2000. Nickel and copper sorption in acid forest soils. J. Soil Sci. 165(6): 463-472. 